\title{
ASIMETRI INFORMASI, LEVERAGE, DAN UKURAN PERUSAHAAN PADA MANAJEMEN LABA
}

\author{
Putu Tiya Mahawyahrti ${ }^{1}$ \\ I Gusti Ayu Nyoman Budiasih ${ }^{2}$ \\ ${ }^{1,2}$ Fakultas Ekonomi dan Bisnis Universitas Udayana, Bali, Indonesia \\ email: tiyamahawyahrti93@yahoo.com
}

\begin{abstract}
ABSTRAK
Penelitian ini bertujuan untuk memperoleh bukti empiris pengaruh dari asimetri informasi, leverage, dan ukuran perusahaan pada manajemen laba. Riset ini menggunakan teori agensi dan teori akuntansi positif untuk menjelaskan pengaruh asimetri informasi, leverage, dan ukuran perusahaan pada manajemen laba. Penelitian ini dilakukan pada perusahaan manufaktur yang terdaftar di Bursa Efek Indonesia periode 2009-2013. Sampel ditentukan dengan menggunakan metode purposive sampling. Jumlah sampel yang terpilih adalah 39 perusahaan. Teknik analisis data yang digunakan adalah analisis regresi linier berganda. Berdasarkan analisis yang telah dilakukan, penelitian ini membuktikan bahwa asimetri informasi berpengaruh positif pada manajemen laba, leverage berpengaruh positif pada manajemen laba dan ukuran perusahaan berpengaruh negatif pada manajemen laba.
\end{abstract}

Kata kunci: Asimetri informasi, leverage, ukuran perusahaan, manajemen laba

\section{ASYMMETRY INFORMATION, LEVERAGE AND FIRM SIZE ONEARNING MANAGEMENT}

\begin{abstract}
This study aims at finding the empirical evidence of the effect of asymmetry information, leverage, and firm size on earning management. This research uses agency theory and positive accounting theory to explain the effect of asymmetry information, leverage, and firm size on earning management. This study was conducted on companies listed in Indonesia Stock Exchange during the period of 2009-2013. The samples were selected by purposive sampling method. The number of selected samples were 39 companies. Multiple linear regression analysis was used to analyze the data. Based on the data analysis, the study proves that the asymmetry information has positive effects on earning management, leverage has positive effects on earning management and firm size has negative effects on earning management.
\end{abstract}

Keywords: Asymmetry information, leverage, firm size and earnings management

DOI: https://doi.org/10.24843/JIAB.2016.v11.i02.p05

\section{PENDAHULUAN}

Laporan keuangan merupakan sarana mengkomunikasikan informasi keuangan kepada pihak-pihak di luar korporasi. Laporan keuangan diharapkan dapat memberikan informasi kepada para investor dan kreditor dalam mengambil keputusan yang berkaitan dengan investasi.

Dasar akrual dipilih dalam penyusunan laporan keuangan karena lebih rasional dan adil serta mencerminkan kondisi keuangan perusahaan secara riil. Akuntansi berbasis akrual mempunyai keunggulan karena informasi laba perusahaan dan pengukuran komponennya berdasarkan akuntansi akrual secara umum memberikan indikasi lebih baik tentang kinerja ekonomi perusahaan dibandingkan Akuntansi berbasis kas yang hanya memperhatikan aspek penerimaan dan pengeluaran kas saja (FASB, 1978). Akuntansi akrual juga memiliki kelemahan, salah satunya adalah memberikan keleluasaan kepada pihak manajemen dalam memilih metode akuntansi selama tidak menyimpang dari Standar Akuntansi Keuangan yang berlaku.

Apabila suatu kondisi dimana pihak manajemen ternyata tidak berhasil mencapai target laba yang ditentukan, maka manajemen akan memanfaatkan fleksibelitas yang diperbolehkan standar akuntansi dalam menyusun laporan keuangan untuk memodifikasi laba yang dilaporkan. Manajemen termotivasi untuk memperlihatkan kinerja yang baik dalam menghasilkan nilai atau keuntungan maksimal bagi perusahaan sehingga manajemen cenderung memilih dan menerapkan metode akuntansi yang dapat memberikan informasi laba lebih baik (manajemen laba).

Badruzaman (2010) mendefinisikan manajemen laba adalah suatu cara yang ditempuh manajemen 
dalam mengelola laporan keuangan perusahaan melalui pemilihan kebijakan akuntansi tertentu dengan tujuan meningkatkan laba bersih dan nilai perusahaan sesuai dengan harapan manajemen. Manajemen laba diduga muncul dan dilakukan oleh manajer atau para penyusun laporan keuangan dalam proses perlaporan keuangan suatu perusahaan karena mereka mengharapkan suatu manfaat dari tindakan tersebut.

Manajemen laba merupakan topik yang menarik, baik bagi peneliti akuntansi maupun praktisi. Fenomena manajemen laba juga telah meramaikan dunia bisnis dan pemberitaan pers. Beberapa bukti empiris dan sistematik yang menunjukkan fenomena manajemen laba, diantaranya Gu dan Lee (1999), De Angelo (1988), serta Holthausen dan Sloan (1995). Secara khusus, $\mathrm{Gu}$ dan Lee (1999) telah menunjukkan bahwa manajemen laba telah meluas dan ada di setiap pelaporan keuangan yang disampaikan oleh perusahaan. Mereka memberikan suatu bukti bahwa manajemen laba terjadi di setiap laporan keuangan kuartalan, dan tingkat manajemen laba terbesar ditemukan pada kuartal ketiga. Ini menunjukkan bahwa praktek manajemen laba merupakan suatu fenomena yang umum terjadi, tidak hanya pada peristiwa-peristiwa tertentu saja tetapi telah mengakar dalam kehidupan bisnis.

Rahmawati (2006) menyatakan bahwa asimetri informasi dapat memicu timbulnya manajemen laba. Teori keagenan (Agency Theory) mengimplikasikan adanya asimetri informasi antara manajer sebagai agen dan pemilik (dalam hal ini adalah pemegang saham) sebagai prinsipal. Asimetri informasi muncul ketika manajer lebih mengetahui informasi internal dan prospek perusahaan di masa yang akan datang dibandingkan pemegang saham dan stakeholder. Kondisi tersebut memberikan kesempatan kepada pihak manajemen untuk menggunakan informasi yang di ketahui untuk memanipulasi keuangan perusahaan guna memaksimalkan kemakmurannya. Semakin banyak informasi perusahaan yang dimiliki oleh manajer daripada pemegang saham maka manajer akan lebih banyak mempunyai kesempatan untuk melakukan manajemen laba. Fleksibelitas manajemen untuk mengelola manajemen laba dapat dikurangi dengan menyediakan informasi yang lebih berkualitas bagi pihak luar (Richardson, 1998 dalam Arief dan Bambang, 2007). Rahmawati dkk (2006) berpendapat bahwa asimetri informasi berpengaruh secara signifikan terhadap manajemen laba.

Leverage adalah rasio yang digunakan untuk mengukur sejauh mana perusahaan dibiayai oleh utang (Riyanto, 1995). Rasio ini menggambarkan hubungan antara utang perusahaan terhadap modal maupun aset. Menurut Horne (1997) Financial Leverage merupakan penggunaan sumber dana yang memiliki beban tetap, dengan harapan akan memberikan tambahan keuntungan yang lebih besar dari beban tetap, sehingga keuntungan pemegang saham bertambah. Menurut Beneish dan Press (dalam Herawaty dan Baridwan, 2007), perusahaan yang melanggar perjanjian utang secara potensial menghadapi berbagai kemungkinan, seperti peningkatan tingkat bunga dan negosiasi ulang masa utang. Utang dapat meningkatkan manajemen laba saat perusahaan ingin mengurangi kemungkinan pelanggaran perjanjian utang dan meningkatkan posisi tawar perusahaan selama negosiasi utang (Klein dan Zhegal, 2006). Perusahaan yang mempunyai rasio leverage tinggi akibat besarnya jumlah utang dibandingkan dengan aktiva yang dimiliki perusahaan, diduga melakukan earnings management karena perusahaan terancam default yaitu tidak dapat memenuhi kewajiban pembayaran utang pada waktunya. Perusahaan akan berusaha menghindarinya dengan membuat kebijaksanaan yang dapat meningkatkan pendapatan maupun laba, dengan demikian akan memberikan posisi bargaining yang relatif lebih baik dalam negosiasi atau penjadwalan utang-utang perusahaan (Jiambalvo, 1996 dalam Widyaningdyah, 2001).

Selain asimetri informasi dan leverage, faktor lain yang diduga memengaruhi manajemen laba adalah ukuran perusahaan. Ukuran perusahaan merupakan nilai yang menunjukkan besar kecilnya ukuran perusahaan. Terdapat dua pandangan tentang bentuk hubungan ukuran perusahaan dengan manajemen laba. Pandangan pertama menyatakan bahwa ukuran perusahaan memiliki hubungan positif dengan manajemen laba. Moses (1997) menyatakan bahwa perusahaan besar memiliki aktivitas operasional yang lebih kompleks dibandingkan dengan perusahaan kecil, sehingga lebih memungkinkan untuk melakukan manajemen laba. Pandangan kedua menurut Marrakchi et. al., (2001), menyatakan bahwa ukuran perusahaan memiliki hubungan negatif dengan manajemen laba. Perusahaan yang berukuran besar memiliki kecenderungan melakukan manajemen laba yang lebih kecil dibandingkan dengan perusahaan yang berukuran kecil. Hal ini dikarenakan perusahaan besar dipandang lebih kritis oleh pemegang saham dan pihak luar sehingga perusahaan besar mendapatkan tekanan yang lebih kuat untuk menyajikan laporan keuangan yang credible (Marihot dan Setyawan, 2007). 
Berdasarkan latar belakang yang telah disampaikan, maka dapat dirumuskan masalah yang akan diteliti dalam penelitian ini adalah: Apakah asimetri informasi, leverage dan ukuran perusahaan berpengaruh pada manajemen laba.

Penelitian ini diharapkan dapat memberikan manfaat secara teoritis dan praktis. Kegunaan teoritis diharapkan penelitian ini dapat menambah referensi dalam rangka pengembangan ilmu pengetahuan, khususnya mengenai asimetri informasi, leverage dan ukuran perusahaan pada manajemen laba. Kegunaan praktis bagi akademisi diharapkan penelitian ini dapat memberikan kontribusi pada literatur akuntansi keuangan tentang asimetri informasi, leverage, ukuran perusahaan dan juga tentang manajemen laba. Sedangkan kegunaan praktis bagi praktisi diharapkan penelitian ini dapat membantu investor sebagai bahan pertimbangan dalam pengambilan keputusan dalam berinvestasi.

Teori keagenan mendeskripsikan hubungan antara pemegang saham (shareholders) sebagai prinsipal dan manajemen sebagai agen. Menurut Jensen dan Meckling (1976), hubungan keagenan merupakan suatu kontrak dimana satu atau lebih orang (prinsipal) memerintah orang lain (agen) untuk melakukan suatu jasa atas nama prinsipal serta memberi wewenang kepada agen membuat keputusan yang terbaik bagi prinsipal. Jika kedua belah pihak tersebut mempunyai tujuan yang sama untuk memaksimumkan nilai perusahaan, maka diyakini agen akan bertindak dengan cara yang sesuai dengan kepentingan prinsipal. Pemisahan yang terjadi antara kepemilikan dan pengelolaan perusahaan akan menimbulkan suatu konflik yang disebut dengan agency conflict (Ahmad dan Septriani, 2008). Biasanya ada tiga jenis konflik keagenan yang sering terjadi, yaitu konflik antara pemegang saham dengan manajemen, konflik antara pemegang saham dengan pemegang utang, dan konflik antara pemegang saham mayoritas dengan minoritas (Purwantini, 2011).

Masdupi (2005) mengemukakan cara-cara untuk mengatasi masalah keagenan antara lain meningkatkan kepemilikan manajerial. Dengan adanya kepemilikan saham maka manajer akan merasakan langsung manfaat dari keputusan yang diambil dan juga merasakan apabila ada kerugian yang timbul sebagai konsekuensi dari pengambilan keputusan yang salah; pendekatan pengawasan eksternal. Pendekatan ini dilakukan melalui penggunaan utang. Adanya utang akan dapat mengendalikan penggunaan free cash flow secara berlebihan oleh manajer karena perusahaan harus melakukan pembayaran atas bunga dan pokok pinjaman secara periodik serta mematuhi ketentuan pada perjanjian utang; institutional investor sebagai monitoring agent. Adanya kepemilikan saham oleh investor institusional seperti perusahaan asuransi, bank, perusahaan investasi dan kepemilikan oleh intitusi lain akan mendorong peningkatan pengawasan yang lebih optimal terhadap kinerja manajemen.

Jensen dan Meckling (1976) mendefinisikan biaya keagenan (agency cost) sebagai jumlah dari biaya yang dikeluarkan prinsipal untuk melakukan pengawasan terhadap agen. Hampir mustahil bagi perusahaan untuk memiliki zero agency cost dalam rangka menjamin manajer akan mengambil keputusan yang optimal dari pandangan shareholders karena adanya perbedaan kepentingan yang besar diantara mereka.

Eisenhardt (dalam Sam'ani, 2008) menyatakan bahwa teori agensi menggunakan tiga asumsi sifat manusia yaitu: manusia pada umumya mementingkan diri sendiri (self interest), manusia memiliki daya pikir terbatas mengenai persepsi masa mendatang (bounded rationality), dan manusia selalu menghindari resiko (risk averse). Dengan adannya asumsi sifat dasar manusia tersebut maka seorang manajer akan cenderung bertindak oportunis, yaitu lebih mengutamakan kepentingan pribadinya dan hal tersebut memicu terjadinnya konflik keagenan. Teori ini memiliki asumsi bahwa setiap individu sematamata termotivasi oleh kepentingan dirinya sendiri sehingga menimbulkan konflik kepentingan antara principal dan agent (Usadha dan Gerianta, 2009). Oleh karena itu teori keagenan lebih menekankan pada penentuan kontrol yang efisiensi dalam hubungan pemilik dengan agen. Dengan demikian dibutuhkan kontrak yang efisien yaitu kontrak yang jelas untuk masing-masing pihak yang berisi tentang hak dan kewajiban, dengan demikian dapat meminimumkan konflik keagenan.

Teori akuntansi positif berupaya menjelaskan sebuah proses, yang menggunakan kemampuan, pemahaman, dan pengetahuan akuntansi serta penggunaan kebijakan akuntansi yang paling sesuai untuk menghadapi kondisi tertentu dimasa mendatang. Teori akuntansi positif pada prinsipnya beranggapan bahwa tujuan dari teori akuntansi adalah untuk menjelaskan dan memprediksi praktekpraktek akuntansi.

Hipotesis kontrak utang dalam teori akuntansi positif menjelaskan bahwa semua hal lain dalam keadaan tetap, makin dekat suatu perusahaan 
terhadap pelanggaran pada akuntansi yang didasarkan pada kesepakatan utang, maka kecenderungannya adalah semakin besar kemungkinan manajer perusahaan memilih prosedur akuntansi dengan perubahan laba yang dilaporkan dari periode masa depan ke periode masa kini. Alasannya adalah laba yang dilaporkan yang makin meningkat akan menurunkan kelalaian teknis. Sebagian besar dari perjanjian utang berisi kesepakatan bahwa pemberi pinjaman harus bertemu selama masa perjanjian. Sebagai contoh, perusahaan yang mendapat pinjaman akan sepakat memelihara level tertentu dari utang terhadap harta, laporan bunga, modal kerja, dan harta pemilik saham. Jika kesepakatan semacam dikhianati, kreditor bisa memberikan atau mengeluarkan penalti, seperti pembatasan dividen atau tambahan pinjaman.

Pelanggaran atas kesepakatan akan membatasi kegiatan operasional perusahaan. Cara mencegah atau menunda pelanggaran, perusahaan bisa memilih kebijakan akuntansi tertentu yang bisa meningkatkan laba masa kini. Berdasarkan hipotesis kesepakatan utang, ketika perusahaan mendekati kelalaian atau memang sudah berada dalam lalai atau cacat, lebih cenderung untuk melakukan manajemen laba (memilih kebijakan akuntansi).

Asimetri informasi merupakan suatu keadaan dimana manajer memiliki akses informasi atas prospek perusahaan yang tidak dimiliki oleh pihak luar perusahaan. Keberadaan asimetri informasi dianggap sebagai penyebab manajemen laba. Richardson (1998) berpendapat bahwa terdapat hubungan sistematis antara asimetri informasi dengan tingkat manajemen laba. Adanya asimetri informasi akan mendorong manajer untuk menyajikan informasi tidak sebenarnya terutama jika informasi tersebut berkaitan dengan pengukuran kinerja manajer. Fleksibelitas manajemen untuk melakukan manajemen laba dapat dikurangi dengan menyediakan informasi yang lebih berkualitas bagi pihak luar. Kualitas laporan keuangan akan mengurangi tingkat manajemen laba.

Beberapa peneliti menemukan bahwa asimetri informasi dapat mempengaruhi manajemen laba. Teori keagenan (agency theory) mengimplikasikan adanya asimetri informasi antara agen (manajer) dan prinsipal (pemilik atau pemegang saham). Asimetri informasi muncul ketika manajer lebih mengetahui informasi internal dan prospek perusahaan di masa yang akan datang dibandingkan pemegang saham dan stakeholder lainnya. Jika dikaitkan dengan peningkatan nilai perusahaan, ketika terdapat asimetri informasi, manajer dapat memberikan sinyal mengenai kondisi perusahaan kepada investor guna memaksimalkan nilai saham perusahaan. Sinyal yang diberikan dapat dilakukan melalui pengungkapan (disclosure) informasi akuntansi.

Asimetri informasi dapat mempengaruhi praktek manajemen laba yang dilakukan oleh manajer, seperti yang dikemukakan oleh penelitian Richardson (1998). Ketika asimetri informasi tinggi, stakeholder tidak memiliki sumber daya yang cukup atas informasi yang relevan dalam memonitor tindakan manajer sehingga akan memunculkan praktek manajemen laba. Akibatnya asimetri informasi ini akan mendorong manajer untuk tidak menyajikan informasi selengkapnya jika informasi tersebut berkaitan dengan pengukuran kinerja manajer. Sesuai dengan penelitian Rahmawati (2006) bahwa asimetri informasi mempunyai pengaruh signifikan positif terhadap manajemen laba, begitu juga dengan penelitian yang dilakukan oleh Desmiyawati (2009) dan Muliati (2011).

$\mathrm{H}_{1}$ : Asimetri informasi berpengaruh positif pada manajemen laba.

Leverage merupakan pengukur besarnya aktiva yang dibiayai dengan utang. Leverage sebagai salah satu usaha peningkatan laba perusahaan, dapat menjadi tolok ukur dalam melihat perilaku manajer dalam hal manajemen laba. Perusahaan yang memiliki financial leverage tinggi, diduga melakukan manajemen laba karena perusahaan terancam default, yaitu tidak dapat memenuhi kewajiban membayar utang pada waktunya. Keadaan ini mengindikasikan bahwa perusahaan dengan leverage tinggi memiliki pengawasan yang lemah terhadap manajemen yang menyebabkan manajemen dapat membuat keputusan sendiri, dan juga menetapkan strategi yang kurang tepat.

Penelitian yang dilakukan oleh Husnan (2001) menyebutkan bahwa leverage yang tinggi disebabkan oleh kesalahan manajemen dalam mengolah keuangan perusahaan atau penerapan strategi yang kurang tepat dari pihak manajemen. Kurangnya pengawasan selain menyebabkan leverage yang tinggi juga akan meningkatkan perilaku oportunis manajemen seperti melakukan manajemen laba untuk mempertahankan kinerjanya di mata pemegang saham dan publik.

$\mathrm{H}_{2}$ : Leverage berpengaruh positif pada manajemen laba.

Ukuran perusahaan adalah suatu skala dimana dapat diklasifikasikan besar kecilnya perusahaaan menurut berbagai cara antara lain dengan total aktiva, penjualan bersih, dan kapitalisasi pasar perusahaan. 
Perusahaan yang berukuran besar memiliki basis pemegang kepentingan yang lebih luas, sehingga berbagai kebijakan perusahaan besar akan berdampak lebih besar terhadap kepentingan publik dibandingkan dengan perusahaan kecil. Bagi investor, kebijakan perusahaan akan berimplikasi terhadap prospek cash flow dimasa yang akan datang. Sedangkan bagi regulator (pemerintah) akan berdampak terhadap besarnya pajak yang akan diterima, serta efektifitas peran pemberian perlindungan terhadap masyarakat secara umum.

Marrakchi (2001) di Amerika Serikat dengan menggunakan data sampel perusahaan industri tahun 1996 menemukan bahwa ukuran perusahaan memiliki hubungan negatif dengan manajemen laba. Perusahaan yang lebih besar kurang memiliki dorongan untuk melakukan manajemen laba dibandingkan perusahaan-perusahaan kecil, karena perusahaan besar dipandang lebih kritis oleh pemegang saham dan pihak luar. Perusahaan besar memiliki basis investor yang lebih besar, sehingga mendapat tekanan yang lebih kuat untuk menyajikan pelaporan keuangan yang kredibel. Penelitian yang dilakukan oleh Veronica dan Siddharta (2005) di BEJ (BEI) pada periode pengamatan 1995-1996 dan 1999-2002, menemukan ukuran perusahaan berhubungan negatif signifikan pada manajemen laba. $\mathrm{H}_{3}$ : Ukuran perusahaan berpengaruh negatif pada manajemen laba.

\section{METODE PENELITIAN}

Penelitian ini dilakukan pada perusahaan manufaktur yang terdaftar di Bursa Efek Indonesia (BEI) periode 2009-2013, dengan mengunduh annual report yang diakses melalui situs www.idx.co.id. Obyek penelitian dalam penelitian ini adalah manajemen laba pada perusahaan manufaktur yang terdaftar di Bursa Efek Indonesia periode 2009-2013.

Manajemen Laba (Y) adalah derajat atau korelasi laba akuntansi suatu perusahaan (entitas) dengan laba ekonominya. Untuk mengukur manajemen laba dilakukan dengan menggunakan proksi discretionary accrual dengan menggunakan Modified Jones Model karena berdasar Dechow et al. (1995). Model ini lebih baik dibanding model Jones standar dalam mengukur kasus manipulasi pendapatan. Menurut Muliati, 2013 model penghitungannya adalah sebagai berikut :

TACit= Nlit-CFOit

Kemudian menghitung nilai total accrual (TAC) yang diestimasi dengan persamaan regresi berikut:
TACit/TAit-1= $\alpha$ i(1/TAit-1) $+\beta 1$ i("REVit/TAit-1) $+\beta 2 \mathrm{i}($ PPEit/TAit-1) $+\varepsilon$

Dengan menggunakan koefisien regresi diatas maka dapat dihitung nilai nondiscretionary accrual (NDTA) dengan rumus:

NDTACit= $\alpha \mathrm{i}(1 /$ TAit-1) $+\beta 1 \mathrm{i}(($ ("REVit-"RECit $) /$ TAit-1) $+\beta 2$ i (PPEit/TAit-1) $+\varepsilon$.

Discretionary accrual (DTA) merupakan residual yang diperoleh dari estimasi total accrual yang dihitung sebagai berikut:

DTAC $=($ TACit/TAit-1 $)-$ NDTACit

Keterangan:

DTACit = Discretionary accrual perusahaan $\mathrm{i}$ pada periode $\mathrm{t}$

NDTACit $=$ Non Discretionary accrual perusahaan i pada periode $\mathrm{t}$

NIit $=$ Net income perusahaan i pada periode $\mathrm{t}$

TACit $=$ Total accrual perusahaan i pada periode $\mathrm{t}$

CFOit = Aliran arus kas operasi perusahaan $\mathrm{i}$ pada periode $\mathrm{t}$

TAit-1 = Total aktiva perusahaan $\mathrm{i}$ pada periode $\mathrm{t}$ $\triangle \mathrm{REVit}=$ Perubahan penjualan perusahaan i pada periode $\mathrm{t}$

PPEit = Aktiva tetap perusahaan $\mathrm{i}$ pada periode $\mathrm{t}$ $\triangle$ RECit $=$ Perubahan piutang perusahaan i pada periode $\mathrm{t}$

Asimteri Informasi $\left(\mathrm{X}_{1}\right)$ dalam penelitian ini asimetri informasi diukur dengan bid-ask spread secara tahunan. Asimetri informasi diukur dengan menggunakan Relative Bid-ask Spread, dimana asimetri informasi dilihat dari selisih harga saat ask dengan harga bid saham perusahaan atau selisih harga jual dan harga beli saham perusahaan selama satu tahun (Healy, 1999 dalam Firdaus, 2013).

Spread $=\frac{\text { ask price }- \text { bid price }}{(\text { ask price }+ \text { bid price }) / 2} \times 100 \% \ldots$..(5)

Sumber: Agusti dan Pramesti, 2008

Keterangan :

Spread = Selisih harga ask (jual) dengan harga bid (beli) saham perusahaan

Ask price $=$ harga ask (jual) tertinggi saham perusahaan

Bid price = harga bid (beli) terendah saham perusahaan

Leverage $\left(\mathrm{X}_{2}\right)$ diukur dengan menggunakan rasio total utang terhadap total asset (Yamaditya 2014).

Leverage $=\frac{\text { Utang }}{\text { Keterangan }}$

Keterangan : Aktiva

Leverage $=$ Rasio utang terhadap aktiva

Utang = total utang

Aktiva $=$ total aktiva 
Ukuran Perusahaan $\left(\mathrm{X}_{3}\right)$ atau size adalah variabel yang diproksikan dengan total aset perusahaan (Yamaditya ,2014). Total aset dipilih sebagai proksi ukuran perusahaan karena tujuan penelitian mengukur ukuran ekonomi perusahaan

$$
\text { Size }=\text { Ln }(\text { Asset })
$$

Keterangan :

Size : Ukuran perusahaan

Ln : Logaritna natural

Asset : Total aset perusahaan

Jenis data yang digunakan dalam penelitian ini adalah data kuantitatif dan data kualitatif. Data Kuantitatif meliputi laporan keuangan tahunan dan data harga saham harian perusahaan manufaktur yang terdaftar di Bursa Efek Indonesia. Data kualitatif meliputi daftar perusahaan manufaktur yang terdaftar di Bursa Efek Indonesia tahun 20092013 dan profil perusahan manufaktur yang terdaftar di Bursa Efek Indonesia tahun 2009-2013.

Sumber data yang digunakan dalam penelitian ini adalah data sekunder. Penelitian ini menggunakan data sekunder meliputi annual report dan data harga saham harian perusahaan manufaktur yang terdaftar di Bursa Efek Indonesia dengan mengunduh melalui situs resmi BEI www.idx.co.id dan finance. yahoo.com

Populasi dalam penelitian ini adalah perusahaan manufaktur yang terdaftar di Bursa Efek Indonesia dari tahun 2009-2013 yang dapat diakses melalui www.idx.co.id. Perusahaan manufaktur digunakan dalam penelitian ini karena sektor manufaktur memiliki aggota perusahaan yang lebih banyak dibandingkan dengan sektor lainnya, dengan demikian hasil penelitian ini diharapkan dapat mewakili sektor-sektor lainnya yang terdapat di Bursa Efek Indonesia

Sampel akan diambil dari populasi tersebut berdasarkan pendekatan nonprobabilitas menggunakan metode purposive sampling (Sugiyono, 2011:74). Purposive sampling adalah metode penentuan sampel dengan pertimbangan tertentu, dimana anggota sampel akan dipilih sedemikian rupa sehingga sampel yang dibentuk tersebut dapat mewakili sifat-sifat populasi (Sugiyono, 2009). Kriteria- kriteria yang akan digunakan adalah: perusahaan manufaktur yang terdaftar di Bursa Efek Indonesia dan menerbitkan laporan keuangan dan laporan tahunan selama tahun pengamatan berturutturut dari tahun 2009 sampai dengan tahun 2013, perusahaan yang menerbitkan laporan keuangannya menggunakan mata uang rupiah, perusahaan yang memiliki data harga saham harian lengkap selama periode 2009-2013, perusahaan yang menyajikan data secara lengkap mengenai keempat variabel tersebut, seperti laba bersih perusahaan, aliran arus kas operasi, total aktiva, perubahan penjualan, perubahan piutang, harga ask (jual) tertinggi saham perusahaan, harga bid (beli) terendah saham perusahaan dan total utang.

Metode pengumpulan data yang digunakan dalam penelitian ini yaitu metode observasi non participant, yaitu teknik pengumpulan data dengan observasi atau pengamatan dimana peneliti tidak terlibat secara langsung dan hanya sebagai pengamat independen (Sugiyono, 2009).

Tabel 1.

Perusahaan Manufaktur yang Menjadi Sampel Penelitian Berdasarkan Kriteria Pengambilan Sampel

\begin{tabular}{llc}
\hline No & \multicolumn{1}{c}{ Kriteria } & \multicolumn{1}{c}{$\begin{array}{c}\text { Jumlah Pengamatan } \\
\text { Perusahaan Sampel }\end{array}$} \\
\hline 1 & $\begin{array}{l}\text { Perusahaan manufaktur yang terdaftar di Bursa Efek Indonesia } \\
\text { periode 2009-2013. } \\
\text { Perusahaan yang tidak terdaftar secara berturut-turut dari tahun } \\
2009-2013\end{array}$ & 123 \\
3 & $\begin{array}{l}\text { Perusahaan yang tidak menerbitkan laporan keuangannya } \\
\text { menggunakan mata uang rupiah. }\end{array}$ \\
4 & $\begin{array}{l}\text { Perusahaan yang tidak memiliki data harga saham harian } \\
\text { lengkap selama periode 2009-2013. }\end{array}$ \\
5 & $\begin{array}{l}\text { Perusahaan yang tidak menyajikan data secara lengkap } \\
\text { mengenai keempat variable }\end{array}$ & (15) \\
6 & Perusahaan yang memenuhi kriteria sampling. & 39 \\
\hline
\end{tabular}

Sumber: Data diolah, 2015 
Alat analisis yang digunakan dalam penelitian ini adalah teknik analisis regresi linier berganda. Persamaan regresi berganda penelitian ini menggunakan model sebagai berikut:

$$
Y=\alpha+\beta_{1} X_{1}+\beta_{2} \cdot X_{2}+\beta_{3} \cdot X_{3}+\varepsilon
$$

\section{Keterangan:}

$\mathrm{Y} \quad=$ Manajemen Laba

$\alpha \quad=$ Nilai konstanta

$\beta_{1,} \beta_{2} \beta_{3}=$ Koefisien regresi variabel independen

$\mathrm{X}_{1} \quad=$ Asimetri Informasi

$\mathrm{X}_{2}=$ Leverage

$\mathrm{X}_{3}=$ Ukuran Perusahaan

$\varepsilon \quad=$ Standar eror

\section{HASIL DAN PEMBAHASAN}

Populasi dalam penelitian ini perusahaan manufaktur yang terdaftar di Bursa Efek Indonesia (BEI) periode 2009-2013 yang berjumlah 123 perusahaan terlihat pada Tabel 1. Metode penentuan sampel yang digunakan adalah purposive sampling, sehingga didapat sampel penelitian berjumlah 39 perusahaan. Hasil uji statistik deskriptif dalam penelitian ini disajikan pada Tabel 2 untuk memberikan informasi tentang karakteristik proksi dari variabel penelitian.

Tabel 2.

Statistik Deskriptif

\begin{tabular}{lrrrrr}
\hline & N & Minimum & Maximum & \multicolumn{1}{c}{ Mean } & Std. Deviation \\
\hline Manajaemen Laba & 195 & $-0,255$ & 0,651 & 0,067 & 0,109 \\
Asimetri Informasi & 195 & $-0,925$ & 1,811 & 0,676 & 0,365 \\
Leverage & 195 & 0,037 & 1,008 & 0,459 & 0,217 \\
Ukuran Perusahaan & 195 & 25,626 & 31,988 & 28,058 & 1,475 \\
\hline
\end{tabular}

Sumber: Data diolah, 2015

Sebelum model regresi digunakan, perlu menguji kelayakan model. Untuk itu dilakukan pengujian asumsi klasik yang meliputi Uji
Autokorelasi, Uji Multikolinieritas, Uji Heteroskedastisitas dan Uji Normalitas. Tabel 3 menyajikan hasil uji

Tabel 3.

Hasil Uji Asumsi Klasik

\begin{tabular}{lccc}
\hline \multicolumn{1}{c}{ Variabel } & \multicolumn{2}{c}{ Collinearity Statistics } & \multirow{2}{*}{ Sig. } \\
& Tolerance & VIF & 0,000 \\
\hline (Constant) & & & 0,250 \\
Asimetri Informasi & 0,858 & 1,166 & 0,063 \\
Leverage & 0,941 & 1,063 & 0,169 \\
Ukuran Perusahaan & 0,896 & 1,116 & 1.134 \\
Kolmogorov-Smirnov Z & & & 0.210 \\
Asymp. Sig (2-tailed) & & & 1,878 \\
Durbin-Watson & & & \\
\hline
\end{tabular}

Sumber: Data diolah, 2015

Uji normalitas bertujuan untuk menguji apakah model regresi, variabel pengganggu atau residual mempunyai distribusi normal atau tidak. Model regresi yang baik adalah model regresi yang terdistribusi normal. Berdasarkan hasil pengujian pada Tabel 3, diperoleh nilai Asymp sig $K$-S sebesar 0.210 lebih besar dari 0,05 . Hal ini menunjukkan bahwa data dalam model regresi telah terdistribusi normal.

Uji autokorelasi adalah pengujian yang dilakukan untuk mengetahui hubungan yang terjadi di antara anggota dari serangkaian pengamatan yang tersusun pada rangkaian waktu. Untuk mengetahui ada tidaknya autokorelasi, maka digunakan metode Durbin-Watson (DW-test). Nilai DW-test selanjutnya dibandingkan dengan nilai tabel DW menggunakan tingkat signifikansi 5 persen.

Berdasarkan Tabel 3 dapat dilihat bahwa hasil uji autokorelasi menunjukkan nilai D-W sebesar 1,878 dengan nilai $\mathrm{d}_{\mathrm{L}}=1,7345$ dan $\mathrm{d}_{\mathrm{U}}=1,7969$ sehingga $4-\mathrm{d}_{\mathrm{L}}=4-1,7345=2,2655$ dan $4-\mathrm{d}_{\mathrm{U}}=4-$ $1,7969=2,2031$. Oleh karena nilai $d$ statistic 1,878 berada diantara $\mathrm{d}_{\mathrm{U}}$ dan $4-\mathrm{d}_{\mathrm{U}} \quad(1,7969<1,878<$ $2,2031)$ maka pengujian dengan Durbin-Watson 
berada pada daerah tidak ada autokorelasi maka ini berarti pada model regresi tidak terjadi gejala autokorelasi.

Berdasarkan hasil pengujian pada Tabel 3 menunjukkan bahwa semua variabel independen mempunyai nilai tolerance diatas 0,1 dan nilai VIF dibawah 10. Hal ini menunjukkan bahwa tidak terjadi gejala multikolinieritas dalam model regresi ini.
Berdasarkan hasil penelitian yang ditunjukkan pada Tabel 3 dapat dilihat bahwa tingkat signifikansi dari masing-masing variabel bebas memiliki tingkat signifikansi lebih dari 0,05 . Hal ini berarti model regresi yang diujikan bebas dari gejala heteroskedastisitas.

Berdasarkan perhitungan dengan bantuan program SPSS 19, maka hasil analisis regresi linear berganda disajikan pada Tabel 4

Tabel 4.

Hasil Uji Analisis Regresi Linear Berganda

\begin{tabular}{|c|c|c|c|c|c|}
\hline \multirow{2}{*}{ Model } & \multicolumn{2}{|c|}{$\begin{array}{l}\text { Unstandardized } \\
\text { Coefficients }\end{array}$} & \multirow{2}{*}{$\begin{array}{c}\text { Standardized } \\
\text { Coefficients } \\
\text { Beta }\end{array}$} & \multirow{2}{*}{$\mathrm{T}$} & \multirow{2}{*}{ Sig. } \\
\hline & B & $\begin{array}{l}\text { Std. } \\
\text { Error }\end{array}$ & & & \\
\hline$($ Constant $)$ & 0,487 & 0,120 & & 4,043 & 0,000 \\
\hline Asimetri Informasi & 0,052 & 0,011 & 0,308 & 4,770 & 0,000 \\
\hline Leverage & 0,101 & 0,027 & 0,233 & 3,784 & 0,000 \\
\hline Ukuran Perusahaan & $-0,017$ & 0,004 & $-0,261$ & $-4,125$ & 0,000 \\
\hline$F_{\text {hitung }}$ & & & & & 29,613 \\
\hline Sig. $F_{\text {hitung }}$ & & & & & 0,000 \\
\hline $\mathrm{R}^{2}$ & & & & & 0,317 \\
\hline Adjusted $\mathrm{R}^{2}$ & & & & & 0,307 \\
\hline
\end{tabular}

Sumber: Hasil SPSS, 2015

Berdasarkan Tabel 4 dapat dibentuk persamaan regresi linear berganda sebagai berikut: $\mathrm{Y}=0,487+0,052 \mathrm{X} 1+0,101 \mathrm{X} 2-0,017 \mathrm{X} 3+\varepsilon$

Konstanta sebesar 0,487. Ini menunjukkan bahwa jika nilai variabel bebas yaitu asimetri informasi, leverage dan ukuran perusahaan dianggap konstan atau sama dengan nol, maka nilai manajemen laba naik sebesar 0,487 persen.

Koefisien regresi asimetri informasi $\left(\mathrm{X}_{1}\right)$ sebesar 0,052. Ini menunjukkan bahwa jika variabel lain dianggap konstan, maka kenaikan satu persen asimetri informasi akan mengakibatkan nilai manajemen laba naik sebesar 0,052 persen.

Koefisien regresi leverage $\left(\mathrm{X}_{2}\right)$ sebesar 0,101 . Ini menunjukkan bahwa jika variabel lain konstan, maka kenaikan satu persen leverage akan mengakibatkan kenaikan leverage sebesar 0,101 persen.

Koefisien regresi ukuran perusahaan $\left(\mathrm{X}_{3}\right)$ sebesar -0,017. Ini menunjukkan bahwa jika variabel lain konstan, maka kenaikan satu persen ukuran perusahaan akan mengakibatkan penurunan manajemen laba sebesar 0,017 persen.

Berdasarkan Tabel 4 dapat dilihat nilai adjusted $\mathrm{R}^{2}$ sebesar 0,307. Hal ini berarti 30,7 persen dari variansi manajemen laba perusahaan manufaktur yang terdaftar di Bursa Efek Indonesia tahun 20092013 dijelaskan oleh variansi asimetri informasi, leverage, dan ukuran perusahaan, sedangkan sisanya sebesar 69.3 persen dipengaruhi oleh variansi faktorfaktor lain yang tidak dimasukkan dalam model penelitian. Nilai sig. $\mathrm{F}_{\text {hitung }}=0,000<\alpha=0,05$. Ini berarti variabel independen yaitu variansi asimetri informasi, leverage, dan ukuran perusahaan merupakan penjelas yang signifikan secara statistik pada manajemen laba perusahaan manufaktur yang terdaftar di Bursa Efek Indonesia tahun 2009-2013.

Tabel 4 menunjukkan bahwa koefisien t sebesar 4,770 dengan tingkat signifikansi sebesar 0,000 kurang dari taraf nyata 0,05 , maka $\left(\mathrm{H}_{0}\right)$ ditolak dan hipotesis pertama $\left(\mathrm{H}_{1}\right)$ diterima. Hal ini menunjukkan bahwa variabel asimetri informasi secara parsial berpengaruh positif pada manajemen laba. Hasil penelitian ini sejalan dengan penelitian yang dilakukan oleh Rahmawati (2006), Desmiyawati (2009) dan Muliati (2011) yang berpendapat bahwa asimetri informasi berpengaruh positif pada manajemen laba. Teori keagenan (Agency Theory) mengimplikasikan adanya asimetri informasi antara manajer sebagai agen dan pemilik (dalam hal ini adalah pemegang saham) sebagai prinsipal. Ketika asimetri informasi tinggi, stakeholder tidak memiliki sumber daya yang cukup atas informasi yang relevan dalam memonitor tindakan manajer sehingga akan memunculkan praktek manajemen laba. Asimetri informasi akan mendorong manajer untuk tidak menyajikan informasi selengkapnya jika informasi tersebut berkaitan dengan pengukuran kinerja 
manajer. Akibatnya semakin tinggi asimetri informasi, semakin tinggi pula praktek manajemen laba yang dilakukan oleh manajemen.

Tabel 5 menunjukkan bahwa koefisien t sebesar 3,784 dengan tingkat signifikansi sebesar 0,000 kurang dari taraf nyata 0,05 , maka $\left(\mathrm{H}_{0}\right)$ ditolak dan hipotesis pertama $\left(\mathrm{H}_{1}\right)$ diterima. Hal ini menunjukkan bahwa variabel leverage secara parsial berpengaruh positif pada manajemen laba. Hasil penelitian ini sejalan dengan penelitian yang dilakukan oleh Husnan (2001) serta I Guna dan Herawaty (2010) yang berpendapat bahwa leverage berpengaruh positif pada manajemen laba. Hipotesis kontrak utang dalam teori akuntansi positf menyebutkan bahwa perusahaan yang memiliki financial leverage tinggi akibat besarnya utang dibandingkan aktiva, diduga melakukan manajemen laba. Hal ini disebabkan karena perusahaan terancam default, yaitu tidak dapat memenuhi kewajiban membayar utang pada waktunya. Keadaan ini mengindikasikan bahwa perusahaan dengan leverage tinggi memiliki pengawasan yang lemah terhadap manajemen yang menyebabkan manajemen dapat membuat keputusan sendiri, dan juga menetapkan strategi yang kurang tepat. Hal tersebut akan memicu pihak manajemen untuk melakukan manajemen laba.

Tabel 5 menunjukkan bahwa koefisien t sebesar $-4,125$ dengan tingkat signifikansi sebesar 0,000 kurang dari taraf nyata 0,05 , maka $\left(\mathrm{H}_{0}\right)$ ditolak dan hipotesis ketiga $\left(\mathrm{H}_{3}\right)$ diterima. Hal ini menunjukkan bahwa variabel ukuran perusahaan secara parsial berpengaruh negatif pada manajemen laba. Hasil penelitian ini sejalan dengan penelitian yang dilakukan oleh Veronica dan Siddharta (2005) yang berpendapat bahwa ukuran perusahaan berpengaruh negatif pada manajemen laba. Semakin besar total aktiva perusahaan maka akan semakin besar ukuran perusahaan begitu juga sebaliknya. Perusahaan besar kurang memiliki dorongan untuk melakukan manajemen laba dibandingkan perusahaan-perusahaan kecil, karena perusahaan besar lebih banyak mendapat perhatian lebih oleh pemegang saham dan pihak luar. Perusahaan besar memiliki basis investor yang lebih besar, sehingga mendapat tekanan yang lebih kuat untuk menyajikan pelaporan keuangan yang kredibel. Maka, semakin besar ukuran perusahaan, akan menurunkan praktek manajemen laba yang dilakukan oleh manajemen.

\section{SIMPULAN}

Berdasarkan hasil penelitian yang diperoleh melalui pengujian statistik serta pembahasan seperti yang telah diuraikan pada bab sebelumnya, maka dapat disimpulkan bahwa asimetri informasi berpengaruh positif pada manajemen laba; leverage berpengaruh positif pada manajemen laba; ukuran perusahaan berpengaruh negatif pada manajemen laba.

Dalam penelitian ini terdapat beberapa keterbatasan, disarankan untuk penelitian selanjutnya mencermati dan menyempurnakan keterbatasan tersebut. Nilai adjusted $R$ square dalam penelitian ini sebesar 0.307 ini berarti 30,7 persen variasi dalam manajemen laba mampu dijelaskan oleh variabel asimetri informasi, leverage, dan ukuran perusahaan, sementara itu 69,3 persen dipengaruhi oleh variabel lain. Untuk itu kepada peneliti lain diharapkan untuk melakukan penelitian dengan menambahkan variabel-variabel lain ke dalam model. Peneliti lain dapat menambah variabel bebas seperti profitabilitas, kepemilikan manajerial, kepemilikan institusional dan kebijkan deviden.

Penelitian ini hanya meneliti satu sektor perusahaan yang terdaftar di BEI yaitu sektor manufaktur sehingga hasil penelitian ini mungkin tidak dapat mewakili hasil penelitian ke semua sektor yang ada, sehingga diharapkan peneliti berikutnya dapat menambahkan sektor-sektor yang lain atau dapat menggunakan seluruh perusahaan agar menggeneralisasi hasil penelitian.

\section{REFERENSI}

Adnyana Usadha, I Putu, \& Gerianta Wirawan Yasa. (2008). Analisis manajemen Laba dan Kinerja Perusahaan Pengakuisisi sebelum dan sesudah Merger dan Akuisisi di Bursa Efek Indonesia. Jurnal Fakultas Ekonomi, Universitas Udayana, Denpasar

Agusti, Restu dan Pramesti, Tyas. (2008). Pengaruh Asimetri Informasi, Ukuran Perusahaan, Kepemilikan Manajerial terhadap Manajemen Laba. Jurnal Akuntansi. Universitas Riau.

Ahmad, Afridian Wirahadi dan Yossi Septriani. (2008). Konflik Keagenan: Tinjauan Teoritisdan Cara Menguranginya, Jurnal Akuntansi dan Manajemen, 3(2), 47-55

Almilia, L.S., \& Devi, V. (2007). Faktor-faktor yang Mempengaruhi Prediksi Peringkat Obligasi pada Perusahaan Manufaktur yang Terdaftar di Bursa Efek Indonesia, Jurnal Proceeding Seminar Nasional Manajemen SMART, Bandung

Arief, Muh. Jiyantho dan Bambang Agus Pramuka. (2007). Mekanisme Corporate Governance, 
Manajemen Laba dan Kinerja Keuangan. Artikel Simposium Nasional Akuntansi (SNA) $X$, Makasar.

Astika, Ida Bagus Putra. (2009). Manajemen Laba dan Motif yang Melandasinya. Jurnal Akuntansi

Christie, Andrew A., \& Zimmerman, Jerold L. (1994). Efficient and Opportunistic, Choices of Accounting Procedures: Corporate Control Contest. Accounting Review, 539-66.

Dechow, P. M R.G. Sloan, \& A.P. Sweeney. 1995. Detecting Earnings Management. The Accounting Review, 70(2).

Desmiyawati. 2009. Pengaruh Asimetri Informasi dan Ukuran Perusahaan terhadap Manajemen Laba pada Perusahaan Manufaktur yang Terdaftar di Bursa Efek Indonesia. Pekbis Jurnal, 1(3), 180-189

Erkasi, Beta Anggraini Dwi. (2009). Analisis FaktorFaktor yang Mempengaruhi Koefisien Respon Laba pada Saham-Saham Syariah. Skripsi. Fakultas Syaiah Universitas Islam Negeri Sunan Kalijaga.

Finacial Accounting Standards Board (FASB). (1978). Statement of Financial Accounting Concepts No.1: Objectives of Financial Reporting by Business Enterprises, Stamfort, Connecticut

Firdaus, Ilham. (2013). Pengaruh Asimetri Informasi dan Capital Adequacy Ratio terhadap Manajemen Laba. Skipsi. Universitas Negeri Padang

Ghozali, Imam. (2011). Aplikasi Analisis Multivariate dengan Program IBM SPSS19, Badan Penerbit Universitas Diponegoro, Semarang

Gujarati, Damodar. (2003). Ekonometrika Dasar : Edisi Keenam. Jakarta: Erlangga.

Guna, Welvin I., \&Herawaty, Arleen. (2010). Pengaruh Mekanisme Good Corporate Governance, Independensi Auditor, Kualitas Audit dan Faktor Lainnya terhadap Manajemen Laba, Jurnal Akuntansi dan Bisnis. 12(1), 5368.

Hasibuan, Abdul Nasser. (2009). Pengaruh Karakteristik Perusahaan dan Ekonomi Makro terhadap Return Saham LQ-45 di Bursa Efek Indonesia. Tesis. Universitas Sumatera Utara.

Healy, P., \& Wahlen J. 1999. A Review of The Earnings Manajement Literature and Its Implications for Standard Setting. Accounting Horizon, 12(4).
Herawaty, Nurul; Baridwan, Zaki. 2007. Manajemen Laba Pada Perusahaan yang Melanggar Perjanjian Utang. Simposium Nasional Akuntansi $X$, UNHAS, Makassar

Horne, Van James C., \& Wachowicz, John M. (2005). Prinsip-Prinsip Manajemen Keuangan Edisi ke 12. Jakarta: Salemba Empat.

Husnan, Suad. (2001). Manajemen Keuangan Teori Dan Penerapan (Keputusan Jangka Pendek) Buku 2 Edisi 4 Cetakan Pertama.Yogyakarta : BPFE

Ikatan Akuntan Indonesia (IAI). (2009). Standar Akuntansi Keuangan (SAK) Tahun 2009. Salemba Emapat, Jakarta.

Jensen, M. C., \& Meckling, W.H. (1976). Theory of the Firm : Managerial Behavior, Agency Costs and Ownership Structure . Journal of Financial Economics, Oktober, 1976, 3(4), 305-360.

Klein, A. (2002). Audit Commite, Board of Director Characteristics, and Earning Management. Journal of Accounting and economics, 33, 375-400.

Lau, G. dan Lee, S. (1999). Consumers trust in the brand and Link to Brand Loyalty. Journal of Market Focused Management

Madura, Jeff. (2007). Pengantar Bisnis. Buku 2. Edisi ke empat. Salemba Empat, Jakarta.

Mardiyah, Listianingsih. (2005). Pengaruh Sistem Pengukuran Kinerja, Sistem Reward dan Profit Center terhadap Hubungan antara Total Quality Manajemen dengan Kinerja Manajerial, Simposium Nasional Akuntansi VII, Solo.

Marrakchi Chtourou S., Jean Bedard, \& Lucie Courteau. (2001). Corporate Governance and Earning Managemen. Working Paper.

Masdupi, Erni. (2005). Analisis Dampak Struktur Kepemilikan pada Kebijakan Utang dalam Mengkontrol Konflik Keagenan. Jurnal Ekonomi dan Bisnis Indonesia, 2(1), 57-69.

Mayangsari, Sekar. (2001). Manajemen Laba dan Motivasi Manajemen. Media Riset Akuntansi, Auditing, dan Informasi, 1(2)

Moses, Douglas O. 1997. Income Smooting and Incentives; Empirical Using Accounting Changes. The Accounting Review. 12(2) 259-377.

Muliati. 2011. Pengaruh Asimetri Informasi dan Ukuran Perusahaan pada Praktik Manajemen Laba di Perusahaan Perbankan yang Terdaftar di BEI, Skripsi. Universitas Udayana. Denpasar.

Nasution, Marihot, \& Doddy Setyawan. (2007). Pengaruh Corporate Governance Terhadap Manajemen Laba di Industri Perbankan 
Indonesia. Artikel Ilmiah dalam Simposium Nasional Akuntansi X, Makassar.

Othman, B.H., Zhegal, D. 2006. A Study of Earnings Management Motives in the Anglo-American and Euro-Continental Accounting Models: the Canadian and French Cases. The International Journal of Accounting, 41, 406-435.

Purwantini, V.T. 2011. Pengaruh Mekanisme Good Corporate Governance Terhadap Nilai Perusahaan dan Kinerja Keuangan Perusahaan yang Terdaftar di Bursa Efek Indonesia. Jurnal Ekonomi Bisnis dan Perbankan, 19(19), STIE AUB, Surakarta.

Rahmawati, Yacop Suparno, \& Nurul Qomariyah. 2006. Pengaruh Asimetri Informasi Terhadap Praktek Manajemen Laba pada Perusahaan Perbankan Publik yang Terdaftar di Bursa Efek Jakarta. Simposium Nasional Akuntansi 9 Padang.

Richardson, V. J., (1998). Information Asymetry and Earnings Management : Some Evidence, Retrieved March $3^{\text {rd }}$.

Riyanto Bambang. (1995). Dasar-Dasar Pembelanjaan Perusahaan. Edisi keempat, Penerbit BPFE, Yogyakarta.

Sam'ani. (2008). Pengaruh Good Corporate Governance dan Leverage terhadap Kinerja Keuangan pada Perbankan yang Terdaftar di
Bursa Efek Indonesia (BEI) Tahun 2004-2007. Skripsi. Universitas Diponegoro, Semarang.

Scott, W. R. (2000). Financial Accounting Theory, 2nd edition. Prentice Hall Canada Inc

Sugiyono. (2012). Metode Penelitian Bisnis. Bandung : CV. Alfabeta.

Sulistyanto, Sri. (2008). Manajemen Laba: Teori dan Model Empiris, Jakarta: Grasindo.

Sweeney, Amy Patricia. (1994). Debt-Covenant Violations and Managers' Accounting Response. Journal of Accounting and Economics, 17, 281-308.

Veronica, Sylvia N.P Siregar dan Siddharta Utama. (2005). Pengaruh Struktur Kepemilikan, Ukuran Perusahaan, dan Praktek Corporate Governance Terhadap Pengelolaan Laba (Earning Management). Simposium Nasional Akuntansi 8. Solo.

Watts, Ross L and Jerold Zimmerman. (1986). Positive Accounting Theory. Prentice Hall International Inc. New Jersey.

Widyaningdyah, A. U. (2001). Analisis Faktor-Faktor yang Berpengaruh terhadap Earnings Management pada Perusahaan Go Publik di Indonesia. Jurnal Akuntansi Keuangan, 3(2), 89 - 101.

Yamaditya, Vanian. (2014). Pengaruh Asimetri Informasi, Leverage dan Ukuran Perusahaan Terhadap Manajemen Laba (Studi Empiris pada Perusahaan Manufaktur yang Terdaftar di BEI Periode 2011-2013). Skripsi. Fakultas Ekonomika dan Bisnis Universitas Diponogoro. 